\title{
Groundwater Contamination and Its Impact on Labour Productivity: A Case Study of Mehsana District in Gujarat, India
}

\author{
Dr. Indira Dutta (Associate Professor), $_{\text {Ashok Kumar Maurya }}$ (Research Scholer) \\ Centre for Studies in Economics and Planning, School of Social Sciences, Central University of Gujarart \\ Sector 30 Gandhinagar, Gujarat
}

\begin{abstract}
Gujarat, the growth engine of India is shining very brightly in the industrial map of India. Its dynamic economic growth in the form of double digits has done enough environmental damage in several digits. For the last one decade Gujarat is continuously facing continuous depletion of groundwater resources, which is creating various health related problems. Mehsana district of Gujarat is one of the most fluoride affected areas of the Gujarat. Fluoride contamination in Mehsana has brought fluorosis in the marginalised section of the society who faces extreme deprivation. The labourers and the marginal farmers are the worst sufferers because they are not in the position to purify water for drinking purpose. Fluorosis makes them partially disabled and sometimes fully disabled. This has brought diminishing physical working capacity among labourers which in turn has a direct impact on household socio-economic condition. A survey was conducted in five villages of Mehsana district and theses villages are highly fluoride endemic villages. Fluorosis symptoms are visible almost in every family and that has made them to face a distressed socio-economic life. The problems like wage loss, low income, illiteracy and increase health expenditure all have become the order of the day. This research paper aims to analyse the impact of fluorosis on labour productivity in Mehsana district and has made some suggestions to check groundwater contamination.
\end{abstract}

Keywords: Groundwater Contamination, Drinking water, Fluorosis, Labour productivity.

\section{Introduction}

It is a well accepted fact that clean water is a must for human survival. Gujarat is one of the top most developed states of India but it has been observed that in this developed state in district Mehsana labourers are threatened rapidly due to groundwater contamination. Human capital is a key driver of workforce participation. As a component of human capital health is a key factor in a creation of wealth (Mwabu, 1998). Though the relationship between health and wealth in terms of productivity seem to be very simple but it is a quite complicated when we measure health both in macro and micro terms. In district Mehsana labourers are suffering in terms of livelihood due to groundwater contamination. It has been noted that intake of fluoride is higher than optimal level in this district and it is the main reason of dental and skeletal fluorosis. Other health disorder due to consumption of high fluoride in drinking water are noticed in terms of muscular fiber degeneration, low hemoglobin levels, excessive thirst, headache, skin rashes nervousness, urinary track malfunctioning etc. Due to all these the productivity of labourers suffers. Presence of excessive fluoride affects soil fertility and it has a direct negative impact on agriculture too.

Health and labour productivity both are positively correlated with each other. Health is measure as well as a main input of human capital of the labourers and their productivity performance. Laboures in general are quite deprived and neglected class of the economy and face basic problems for their livelihood and pure drinking water is one of them. They are unaware of the disadvantages of water pollution and contamination. In Gujarat, people are suffering from fluorosis caused by drinking groundwater; most of it brought to the surface by hand pumps installed in the past two decade where, excessive natural fluoride is in underground water especially in Mehsana district. It is living a poison in ground as a form of water. When water pumps from deeper then water comes into contact with the fluoride bearer rocks . So it is more fluoride contaminated (Shah, 2004).

\section{Basic Concept Of Labour Health And Its Productivity}

Sound health enhances labour's productivity by increasing their physical capacities, such as strength and endurance, as well as their mental capacities, such as cognitive functioning and reasoning ability. There is a positive relationship between health and productivity for both unskilled and skilled labour. A healthy population is an engine for economic growth. Economic development is dependent on a healthy society and health is the level of functional and metabolic efficiency of a living being. In humans, it is the general condition of a person in the mind, body and spirit, usually meaning to be free from illness, injury or pain. In a simple and important 
sense, health is wealth. If one measures welfare more broadly than income or consumption, poor health is itself a deprivation and that is a part of poverty.

Health impacts directly on household income and wealth, labour productivity, labour force participation, savings and investment rates, demographic factors, and other human capital factors. While some would argue that improved health is among the many positive results of successful economic development strategies, other evidence suggests that such strategies must incorporate effective health interventions (Gallup, Sachs, \& Mellinger 1998).

The effects of ill health on farm households include three broad impacts: absenteeism from work due to morbidity; family time diverted to caring for the sick; and loss of savings and assets in dealing with the disease and its consequences. The long-term impacts of ill health include loss of farming knowledge, reduction of land under cultivation, planting of less labour-intensive crops, reduction of a variety of crops planted, and reduction of livestock. The ultimate impact of ill health is a decline in household income and possible food insecurity that is, a severe deterioration in household livelihood (Okyere, 2011). Amartya Sen (1999) has characterized poverty as "capability deprivation", where a person lacks the "substantive freedoms" he or she needs to lead "the kind of life he or she reason to value". Health used to be viewed as an end product of the growth process. People with higher incomes have a greater command over the goods and services that promote health, such as better nutrition, access to safe water, sanitation, and good-quality health services. Wealth undoubtedly leads to health, but health should also be seen as a form of human capital and therefore an input into the growth process, as well as an output. Countries with educated, healthy populations are in a better position to prosper, especially in a favourable policy environment (Bloom \& Canning, 2000).

Asenso- Okyere, K., F.A. Asante, J. Tarekegn, \& K.S. Andam all together have provided a conceptual framework for the impact of diseases on agricultural workers which has shown in figure 1.

Figure 1: - Conceptual framework for the impact of diseases on agriculture workers

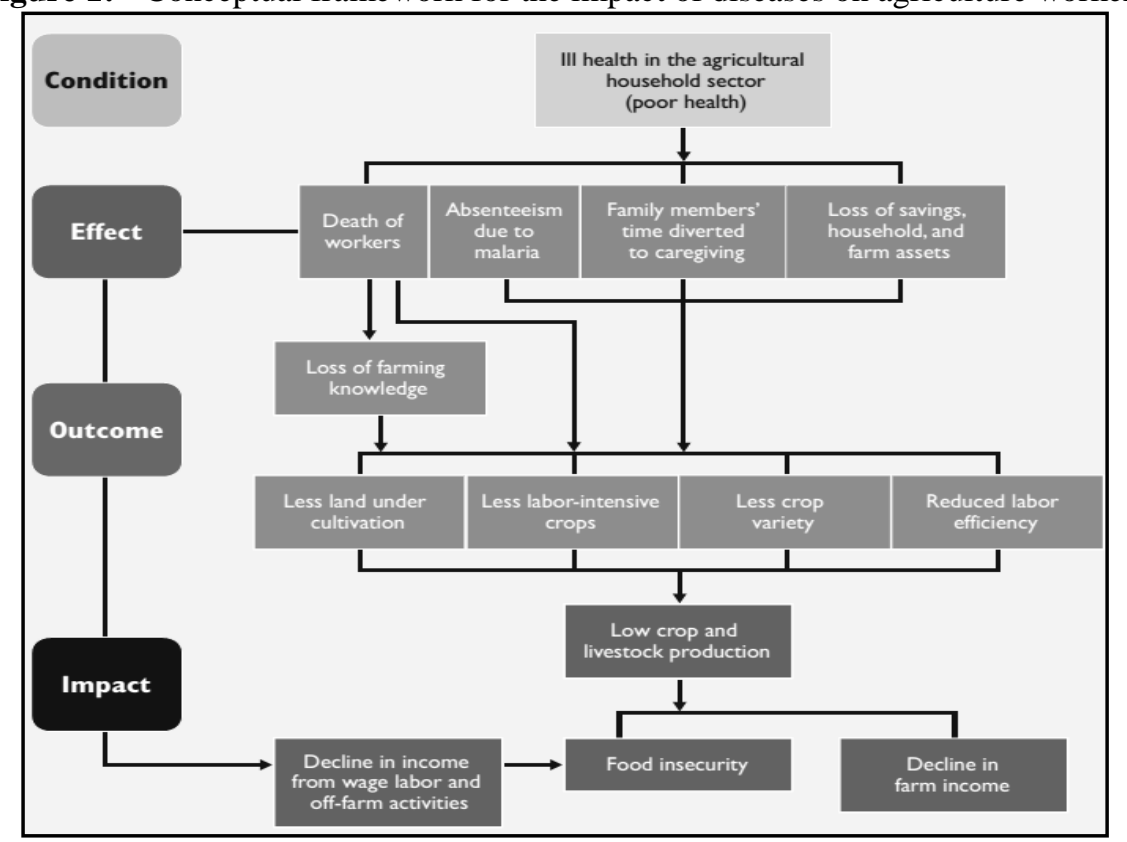

Source- Asenso- Okyere, K., F.A. Asante, J. Tarekegn, \& K.S. Andam, International Food Policy Research Institute, Washington, DC (2009)

The elimination or reduction of poverty is now an important priority of all governments. Good health reflects good standard and quality of life. Physical fitness is the basic asset of poor people because without this they cannot earn money. Good health is an asset for all but for the poor it is an important asset as they are poor in terms of other assets. They have to rely on their health for production and for consumption, while richer people rely more heavily on human and financial capital, thus we expect ill-health to be correlated to poverty, and the correlation is unlikely to go away without doing something about poverty (Muurinen \& Le Grand, 1985). Ill health not only affects the poor disproportionately, it also causes poverty. A health crisis can quickly reverse any progress of the poor who have made in moving up from subsistence. Low income and poor health both combine to form a poverty trap. One of the most sizable and least predictable shocks to the economic opportunities of families is fluorosis. There are two important economic costs associated with illness: the cost of the medical care used to diagnose and treat the illness, and the loss in income associated with reduced labour supply and productivity (Lustig \& Gertler, 2001). The size and unpredictability of both of these costs suggests that families may not be able to insure their consumption over periods of major illness, especially in developing 
countries where few individuals are covered by formal health and disability insurance (World Bank, 1993). Although families with sick members in developing countries are not able to access formal insurance markets, they do rely on private informal coping mechanisms such as drawing on savings, selling assets, transfers from their families and social support networks, and borrowing from local credit markets (Morduch, 1999, Townsend, 1995). Kochar (1996) models wage income and informal borrowing as a function of illness in the family, as measured by a member of the family experiencing a loss of work due to illness. She finds that illness to the male lowers wage income and increases informal borrowing during peak periods in the agricultural cycle, but that there are no effects during slack periods and no effects of female illnesses.

\section{Fluoride And Health Dimensions}

Fluorosis appears in three forms, dental fluorosis, skeletal fluorosis and non-skeletal fluorosis. Malnourished children, pregnant women, lactating mothers and poorer sections of the rural society are highly vulnerable to fluorosis (Duraiswami, 2011). The following table gives a glance of effects of fluoride on human health.

Table 1: - Effects of fluoride on human health

\begin{tabular}{|l|l|}
\hline Fluoride Concentration $(\mathbf{m g} / \mathbf{l})$ & Effects of Fluoride \\
\hline$<\mathbf{0 . 5}$ & Dental carries and poor development of bones \\
\hline $\mathbf{0 . 5}-\mathbf{1 . 5}$ & Promote development of strong bones and teeth \\
\hline $\mathbf{1 . 5}-\mathbf{4 . 0}$ & Promote dental Fluorosis in children \\
\hline $\mathbf{4 . 0}-\mathbf{1 0}$ & Promote dental and skeletal Fluorosis \\
\hline $\mathbf{1 0}$ \& above & Crippling skeletal Fluorosis, cancer \\
\hline
\end{tabular}

Source- Karthikeyan (2008)

Skeletal fluorosis is a bone disease caused by excessive consumption of fluoride. The most common cause of fluorosis is fluoride-laden water derived from bore wells dug deep into the earth. Dental Fluorosis damages the cells responsible for forming tooth enamel. This raises the questions, where does fluoride can accumulate? Whether there are other cells in the body (which we can't see) that fluoride may be damaging particularly in areas like the bone, the pineal gland, and the kidney (Shanker, 2006). Better health depends on awareness and knowledge about causes of disease. The problem of fluorosis is increasing mainly due to illiteracy. Education makes better awareness to the people and most of the people do not believe in medication. Awareness is the second problem, people don't know about this diseases and consequence of the fluorosis. This is big threat to human health which finally has a very negative effect on the economic system.

\section{Accessibly Of Drinking Water And Fluoride Status Of Rural Areas}

When we look towards accessibility of drinking water in Gujarat we notice there are various sources through which people avail drinking water. In the table 2 the major sources of drinking water has been shown both rural area as well as urban area. Groundwater pollution has been emerging one of the major threats to the labour as well as marginal class of the society in Gujarat. The agricultural labours are prone to water contaminated dieses because the quality of water is deteriorating day by day. In rural area, agriculture is main occupation of the livelihood and affects agriculture very badly which has a direct effect on socio- economic condition. It seems that agricultural labourers are more prone to water contaminated diseases. Gujarat is facing water quality crisis due to continuous population growth, urbanization and rapid industrialization. The district Mehsana is facing worst type of water quality crisis.

Table 2:- Distribution of households by major source of drinking water in Gujarat (per thousand households)

\begin{tabular}{|l|l|l|l|l|l|l|}
\hline Major source of drinking water & \multicolumn{2}{|c|}{ Rural } & \multicolumn{2}{c|}{ Urban } & \multicolumn{2}{c|}{ Rural +Urban } \\
\hline & $60^{\text {th }}$ round & $65^{\text {th }}$ round & $60^{\text {th }}$ round & $65^{\text {th }}$ round & $60^{\text {th }}$ round & $65^{\text {th }}$ round \\
\hline Bottled water & 52 & 9 & 92 & 34 & 64 & 19 \\
\hline Tap & 506 & 540 & 796 & 838 & 591 & 682 \\
\hline Tube-well/hand pump & 303 & 284 & 73 & 116 & 235 & 218 \\
\hline Pucca well & 99 & 46 & 14 & 2 & 74 & 29 \\
\hline Tank/pond & 9 & 17 & 0 & 1 & 6 & 11 \\
\hline River/canal (spring, harvested rainwater, & 0 & 13 & 0 & 0 & 0 & 8 \\
\hline $\begin{array}{l}\text { Others } \\
\text { unprotected wells etc) }\end{array}$ & 91 & 25 & 9 & 29 & 29 \\
\hline
\end{tabular}

Sources: - National Sample Survey $60^{\text {th }} \& 65^{\text {th }}$ round

The Table no 2 shows that tab and tubewell water are the main sources of drinking purpose in rural as well as urban area. In Gujarat, most of the tap water is distributed by the groundwater resources because of Narmada is main river of Gujarat and it cannot supply water throughout the year. The main sources of rural water supply has distributed by groundwater resources in rural area. The tab water is generally fluoride contaminated. The pre monsoon survey conducted by Water and Sanitation Management Organization in 2012 has claimed the fluoride status of some villages of Mehsana district. 
Groundwater Contamination and Its Impact on Labour Productivity: A Case Study of Mehsana

Table 3: - Fluoride Status in Some Villages of Mehsana Districts (Pre-monsoon Survey- 2011-12)

\begin{tabular}{|c|c|c|c|}
\hline Taluka & Village & Source & Fluoride (mg/l) \\
\hline Chorale & Amarpur & Tubewell & 3.93 \\
\hline Kheralu & Chotiya & Water of Dharoi GWSS & 1.91 \\
\hline Kheralu & Fatehpura & Tubewell, beside Bus Stand & 2.86 \\
\hline Kheralu & Sadikpur & Well & 2.13 \\
\hline Kheralu & Sankari & Tubewell & 2.17 \\
\hline Satalasana & Bhanavas & Tubewell & 2.34 \\
\hline Satalasana & Bhatvas & Tubewell & 1.82 \\
\hline Satalasana & Khilod & Tubewell & 4.78 \\
\hline Satalasana & Nana Kothasana & Tubewell & 4.02 \\
\hline Satalasana & Nani Bhalu & Water of Dharoi GWSS & 4.26 \\
\hline Satalasana & Sartanpur Gadh & Tubewell, 450fts deep & 2.04 \\
\hline Satalasana & Sudasana & Tubewell & 2.86 \\
\hline Satalasana & Umari & Tubewell & 5.40 \\
\hline Unjha & Bhunav & Tubewell & 1.79 \\
\hline Unjha & Brahmanvada & Tubewell, Gram Panchayat & 3.45 \\
\hline Unjha & Dasaj & Tubewell & 1.84 \\
\hline Unjha & Gangapura & Tubewell & 2.13 \\
\hline Unjha & Hajipur & Tubewell & 2.01 \\
\hline Unjha & Jagannathpura & Tubewell & 2.49 \\
\hline Unjha & Kamali & TW + Dharoi GWSS & 2.56 \\
\hline Unjha & Karali & Tubewell & 2.24 \\
\hline Unjha & Karanpur & Tubewell & 2.33 \\
\hline Unjha & Khatasan & Tubewell & 1.91 \\
\hline Unjha & Lindi & Tubewell & 2.78 \\
\hline Unjha & Maherwada & Tubewell & 2.10 \\
\hline Unjha & Ranchhodpura & Tubewell & 2.19 \\
\hline Unjha & Upera & Tubewell & 2.24 \\
\hline Unjha & Varvada & Tubewell, beside Primary School & 2.96 \\
\hline Unjha & Vishol & Tubewell & 2.90 \\
\hline Vadnagar & Aspa & Tubewell & 3.15 \\
\hline Vadnagar & Aspa Nava & Tubewell & 2.43 \\
\hline Vadnagar & Babipura & Village well, beside Gram Panchayat & 2.08 \\
\hline Vadnagar & Jagapura & Water of Dharoi GWSS & 2.34 \\
\hline Vadnagar & Karasanpura & $\begin{array}{l}\text { Village well, between } \\
\text { Primary School }\end{array}$ & 2.55 \\
\hline Vadnagar & Khanpur & Tubewell & 3.54 \\
\hline Vadnagar & Shahpur & Tubewell & 2.32 \\
\hline Vadnagar & Sultanpura & Tubewell & 1.59 \\
\hline Vadnagar & Vaghadi Juni & Water Tank & 1.80 \\
\hline Vijapur & Agalod & Tubewell & 1.68 \\
\hline Vijapur & Bhanpur & Tubewell & 1.59 \\
\hline Vijapur & Gadhada & Tubewell & 1.96 \\
\hline Vijapur & Jepur & Tubewell & 1.66 \\
\hline Vijapur & Pedhamali & Tubewell, 350fts deep & 1.70 \\
\hline Visnagar & Hasanpur & Tubewell, behind Dairy & 1.55 \\
\hline Visnagar & Umata & Tubewell, near Sharifa Talav & 1.61 \\
\hline
\end{tabular}

Sources: - Water and Sanitation Management Organization, 2012 
The Table no 3 shows that fluoride concentration in groundwater in some villages of Mehsana district. According to Indian standard, up to 1.5 milligram per liter is permissible level in drinking water. This data points towards the threat in groundwater of Mehsana district, has been converted into poison. The groundwater resource has been totally degraded by the fluoride. This is a challenging scenario of the environment and in future, it will create more challenges to environment as well as human being.
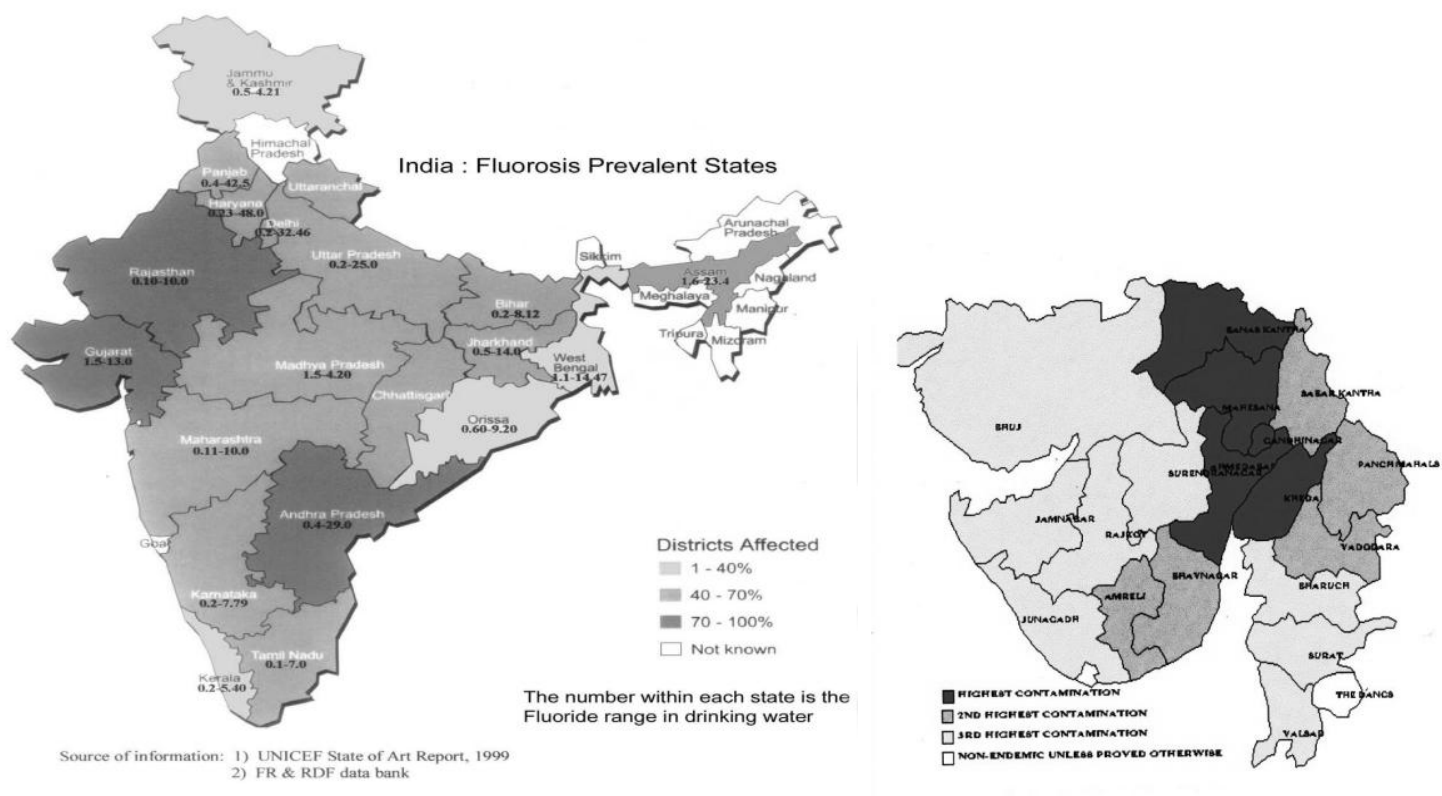

\section{Location And Research Methodology}

For primary data collection the district Mehsana has been selected from North Gujarat and five villages Techava, Rampur Kot, Kot, Navafudeda and Junafudeda have been selected in Vijapur Taluka and number of sample is twenty from each village and total sample selection is one hundred for data analysis. The snowball sampling method has been used for sample selection. The selection of the village is based on sources of drinking water. The main source of the drinking water supply is based on groundwater in all five villages.

After data collection, analysis has been made to find out the health expenditure, wage losses, water supply management and socio-economic condition of the fluorosis affected people.

Secondary sources are based on recent studies and statistical data, project reports, various ministries and deportments reports, report of national and international institutes, case studies, books and journals.

\section{Stark Reality Of Laboures In Mehsana District}

Labourers in district Mehsana remain in a pitiable condition due to groundwater pollution. It has brought both ill health and poverty. Laboures affected by fluorosis remain trapped in a vicious circle of poverty. Fluorosis targets mostly immunologically and physically weak children /adult persons and those who are suffering from mal-nutrition. The influence of environmental, behavioral, social, cultural, economic, and political factors on health and human development has varied throughout history and will continue to vary. The basic determinants of health include genetic makeup, environmental exposures, social circumstances, behavioral patterns, and health care; there are multiple complex interactions at individual and population levels (WHO, 2001). Poor health in turn affects agricultural production. Illness damages the laborer's ability to innovate, experiment, and implement changes in his work, and therefore labourers cannot get good wages. Healthcare expenses may consume resources that otherwise might be used to archive improved education, housing condition, saving for future and other quality work. Households with sick members are less able to adopt laborintensive techniques. In addition, health threats also affect the demand for agricultural output, if they have land. Malnutrition and disease patterns influence the total demand of food, in terms of quantity, quality, diversity, and they are not able or willing to pay an appropriate price for food. The long-term household impacts of fluorosis on marginal farmers include loss of farming knowledge, reduction of land under cultivation, planting of less labor-intensive crops, reduction of variety of crops planted, and reduction of livestock. 
Figure 2: - Occupational distribution of the Household (in percent)

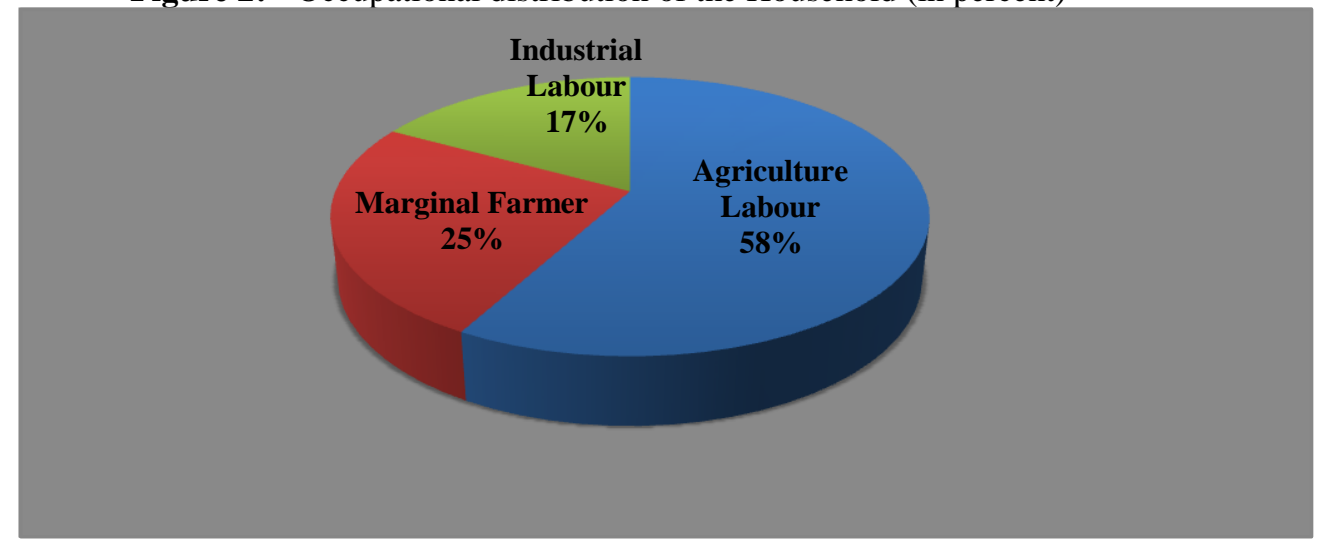

Source: - Primary Survey, 2013

It is clear for the Figure no 2 that most of the affected families belong to the agricultural labourer class. Agriculture labourers are divided into two classes, the marginal farmers and the labour class. Basically, land owners belong to the marginal farmers as they have small pieces of agricultural land.

Healthy workers are physically and mentally more energetic and robust. They are more productive, and earn higher wages. Ill health means that people who are able to work have a reduced productivity, shortened working lives, and increased numbers of days lost to illness. Health and success in education are also clearly linked. Healthy children are able to learn faster and become productive human capital in the long run. In a healthy family, children's education hardly suffers. Health has always been a valued possession. It is still considered the most valuable thing in life. The Millennium Poll, a huge worldwide survey was prepared for the Millennium Report of the Secretary-General of the United Nations, revealed that health is consistently ranked number one in the things that men and women desired in life. Grossman (1972) conceives of health as a 'durable capital stock that produces an output of healthy time'. This healthy time is then allocated between leisure and work, with poor health limiting the amount of healthy time that may be allocated to generating income. This conception of health describes the effects of absenteeism on labour productivity. Now we will analyse the wage loss of the labourers with the help of following figure.

Figure 3: - Wage loss of the labourers after affected by fluorosis (In $\square$ )

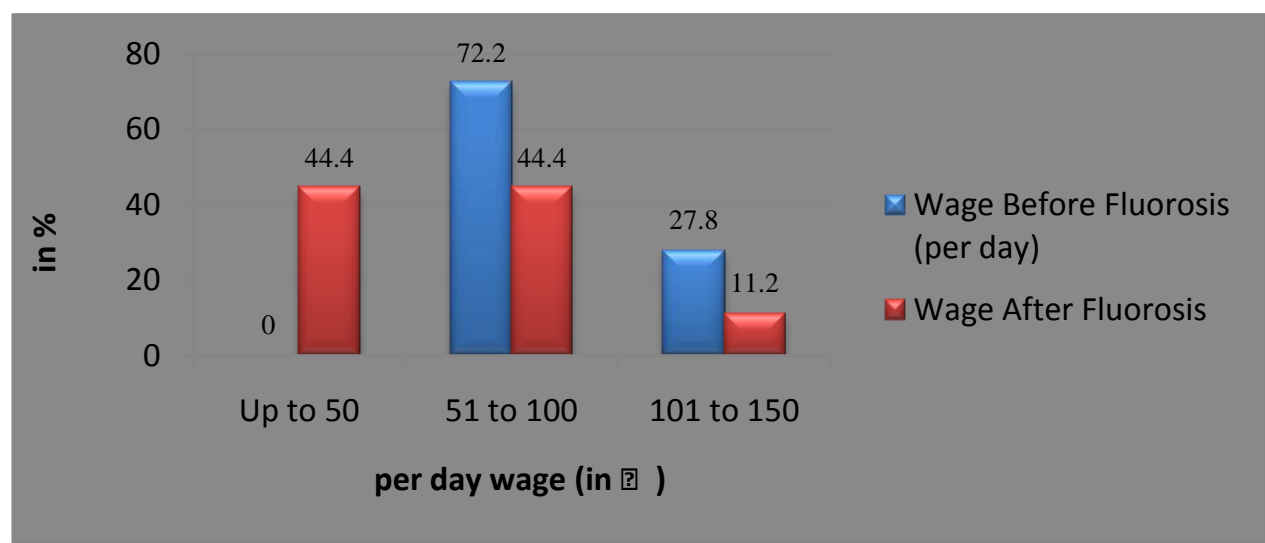

Source: - Primary Survey, 2013

Data in Figure no 3 shows two important insights into the causes of fluorosis; wage of the fluorosis affected laboures have sharply declined after the fluorosis, second is the productivity of skill labourers also decrease after fluorosis. The poor socio-economic condition affects health indirectly, by influencing a set of intermediary factors which take a more direct toll on health. These factors include environmental exposures and health-damaging behaviors. Environmental risks can be physical (e.g. poor housing conditions, drinking water quality, nutrition etc.). For example, the environment plays a larger role for fluorosis, where the physical environment like socioeconomic condition of fluoride affected people is the determining factor.

The Figure 4 shows that most of the affected people fall under the lower income groups. They cannot spend their income on good- quality water and healthy nutrition diet. Without these, they cannot protect their health, and easily succumb to fluorosis. 
Figure 4: - Monthly income of affected families

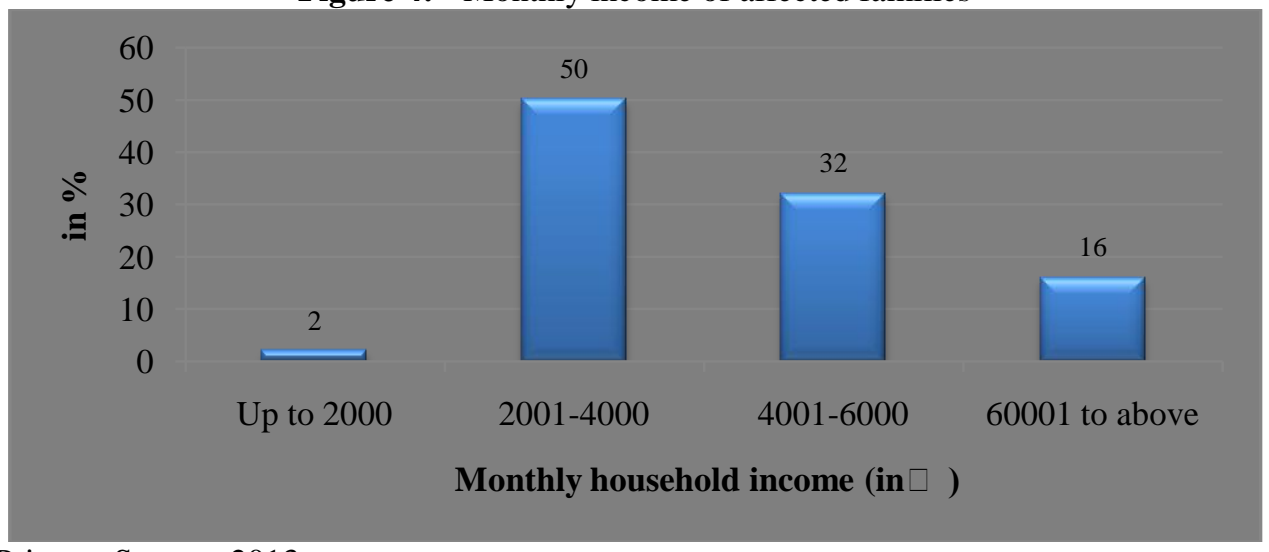

Source: - Primary Survey, 2013

Family income is an important factor for prevention and case of fluorosis. Fluorosis leads to absenteeism or even if they work it gives result in terms of reduced output and productivity of affected workers. Fluoride related weakness prevent them to work. People cannot earn income as before due to fluorosis because of their declining behavioral activities (cycling, walking, lifting load, taking care of children and cattle etc.) and loss in capacity of earning. Once people suffer dental or skeletal fluorosis, they face various types of social problems. Disintegration of social network, which is more likely to occur in area of socio-economic deprivation, has detrimental effects on health that has for potential to spread it among all members of society. Fluorosis changes the behavioral attitude of the people. Family care is important phenomena because affected persons cannot do anything for the others. Most families provide help for their relatives, close friends and neighbors when they are disabled. However, for some people it can become a major responsibility, affecting their paid work, income, social activities and other family relationship. So the role of social aspects of fluorosis affected people is important for the society.

Figure 5: - Economic effect of fluorosis (water born diseases) in agriculture laboures family in Mehsana district

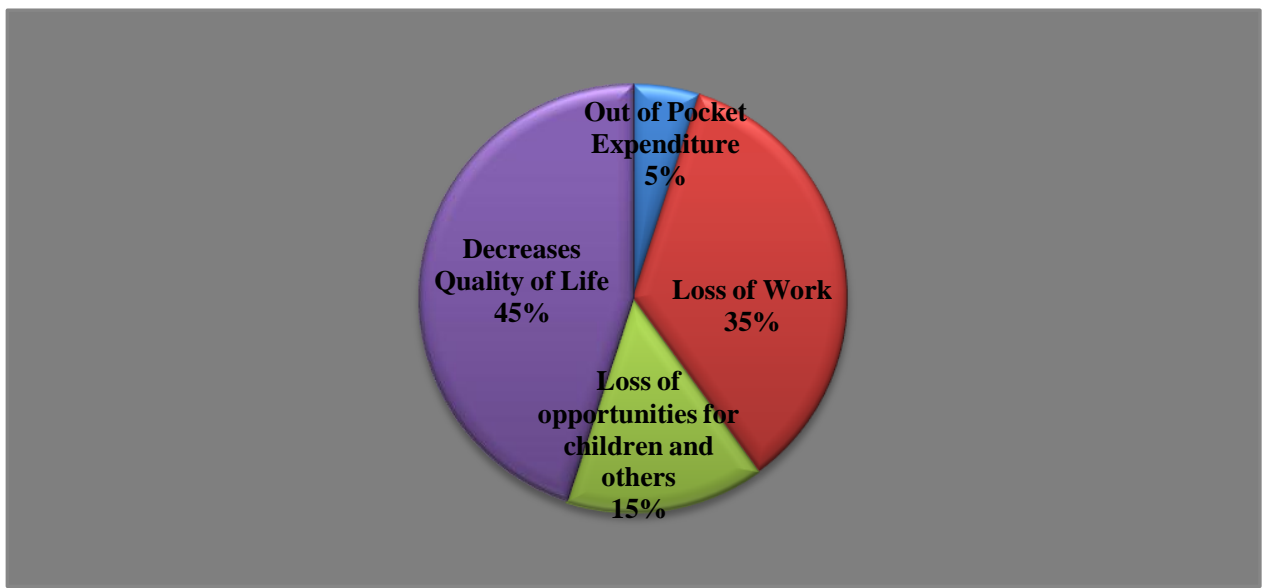

Source: - Maurya, 2013

According to Econtech (2007), the loss of productivity occurs 'when employees come to work, as a consequence of illness or other medical conditions, are not fully functioning' is referred to as 'presenteeism' and it is a source of health-related productivity loss. Better health leads to improved two types of benefits to labour, i.e. superior wages rate and less medical cost. These wages may differ from the marginal product of labour and less money would be spent on illness, and in the long-term, these health gains would benefit not just the individuals concerned, but the wider economy and society. Illness often leads to asset depletion and debt in order to fund private healthcare, and thus is one of the most powerful forces pushing households into poverty. Indeed, there is enough reason to believe that illness forces households to pay extra medical expenditure which can push them deeper into poverty and indebtedness and people can never be out into poverty trap. This reduces the number of working days for ordinary wage earners and self-employed persons. It imposes double side effects on his economic burden, first is wage loss demolish his consumption expenditure on food items, due to this his family member suffer, second is medical cost. In brief laboures have no saving or less saving, extra expenditure constrain to barrowing for medical expenses. 
Socio-economic position refers to an individual's place in the social hierarchies built around education, occupation and income. These three components of socioeconomic position are important because of their determining influence on an individual's life chances and living standards (Graham, 2004). It has been noticed that due to decrease in labour productivity the problems in the socio-economic of the labourers are steadily increasing. This increase is not only limited to small and specific parts but also concerned at a large part of Gujarat including Mehsana district and which finally affects human development. The health picture which emerges as a result of these changes is that in the long run laboures have to face chronic and crippling conditions. Affected families bear a lot of problems due to fluorosis in terms of economic exclusion and social exclusion. Loss of functional capacity can obviously have many social effects on the individual. Because he cannot pursue his former social and vocational activities, he may need considerable assistance in restoring some semblance of a balanced life. His earning power may cease or be reduced, which will add to the problem of adapting his way of life to the new conditions imposed by his disability. He may become much more dependent in every way on his family or upon community institutions and services. If main male breadwinner is suffering from fluorosis then female and children have to go to the work for earning which is really pathetic.

\section{Conclusion}

Water is a prime natural resource, basic human need and precious national asset (National Water Policy, 1987). In district Mehsana it has been noticed that the labourers in large number have to face social and economic exclusion due to groundwater pollution. The Government of Gujarat wants to bring smiles back to the faces of deprived labourers and a host of initiatives were launched making Jal Shakti- a revolution convert into Jeevan Shakti. No doubt watershed development, construction of check dams, Khet talavadis (farm pounds), Boribunds obstructing the flow of water by putting cement filled bags have become government's commitment but if we want to solve the problems of district Mehsana we need people's movement and futuristic approach for conserving water for tomorrow. Groundwater is integral part of environment and hence it cannot be looked upon in isolation. Beside water conservation we have to look into efficiency of water use, water re-use, groundwater recharge and eco system sustainability. We have to check uncontrolled use of borewell technology that has led to the extraction of groundwater at a higher rate. Groundwater crisis of Mehsana is not the result of natural factors but is caused by human factors. Problems and issues suggest water logging salinity, agriculture toxicity and industrial influence must be sincerely taken care of. Water has to be used for regeneration. The government should implement effective groundwater legislation and there should be a participation of communities and local institutions. To make Mehsana a fluoride free district we need good governance so that labourers could enjoy a better tomorrow.

\section{Reference:}

[1]. Asenso- Okyere, K., F.A. Asante, J. Tarekegn, \& K.S. Andam (2009), "The linkage between agriculture and health", International Food Policy Research Institute Discussion Paper 00861, International Food Policy Research Institute, Washington, DC

[2]. Asenso- Okyere, K., Catherine Chiag, Paul Thangata \& Kwaw S. Andam (2011), "Interactions between Health and Farm-Labor Productivity", International Food Policy Research Institute, Food Policy Report, International Food Policy Research Institute, Washington, DC

[3]. Bloom, D, D. Canning \& P. Malaney (2000), "Demographic Change and Economic growth in Asia", Population and Development Review, Vol. 26, pp. 257-290

[4]. Duraiswami, R. D and Uday Patankar (2011), "Occurrence of Fluoride in the Drinking Water Sources from Gad River Basin, Maharashtra", Journal of Geological Society of India, Vol. 77, pp. 167-174.

[5]. Econtech (2007), "Economic modeling of the cost of presenteeism in Australia", Report prepared for Medibank Private Canberra: $\begin{array}{llllllll}\text { Econtech } & \text { Pty } & \text { Ltd. } & \text { Viewed } & 28 & \text { July } & 2009, & \text { Accessed }\end{array}$ http://www.econtech.com.au/information/Social/Medibank_Presenteeism_FINAL.pdf>.

[6]. Gram, H (2004), "Socioeconomic Inequalities in Health in the UK: Evidence on Patterns and Determinants" A short report for the Disability Rights Commission, Institute for Health Research, Lancaster University.

[7]. Gallup, John L., Jeffrey D. Sachs \& Andrew D. Mellinger (1998), "Geography and Economic Development", Chapter in World Bank Annual Conference on Development Economics. Washington, D.C.

[8]. Grossman, M (1972), "The Demand for Health: A Theoretical and Empirical Investigation", NBER Occasional Paper no. 119, Columbia University Press, New York.

[9]. Graham, H (2004), "Socioeconomic Inequalities in Health in the UK: Evidence on Patterns and Determinants" A short report for the Disability Rights Commission, Institute for Health Research, Lancaster University

[10]. Kochar, A (1996), "Explaining household vulnerability to idiosyncratic income shocks", American Economic Review, Vol. 85, pp. $159-164$.

[11]. Karthikeyen, K, et.al (2008), "Prevalence of certain inorganic constituents in groundwater sample of Erode district, Tamil Nadu, India, with special emphasis on fluoride, fluorosis and its remedial measures", Journal of Environmental Assess Vol. 160, pp. 140155 .

[12]. Lustig, N \& P. Gertler (2001), "Health, Shocks and Poverty", Notes prepared for the Commission on Macroeconomics and Health (CMH).

[13]. Maurya, A.K (2013), "Impact of Fluorosis on Agriculture Labour Productivity: A Case Study of North Gujarat", Contemporary Issues of Indian Economy, edited by-Dr. Vinod Sen \& Dr.Indira Dutta, Segment Books, New Delhi

[14]. Muurinen, J. M \& J.Le Grand (1985), "The economic analysis of inequalities in health", Social Science \& Medicine, Vol. 20, No. 10, pp. 1029-1035. 
[15]. Morduch, J (2001), "Between the market and state: can informal insurance patch the safety net? Forthcoming" WDR on Poverty and Development, Stiglitz Summer Research Workshop on Povery, Washington, DC.

[16]. Mwabu, Germano (1998), "Health Development in Africa", Economic Research Papers No. 38, African Development Bank.

[17]. Shah, Tushaar (2004), "Water and Welfare: Critical Issues in India’s Water Future", Economic and Political Weekly, Vol. 39, No. 12, pp. 1211-1213

[18]. Sanker, Ravi (2006), "Small Scale Community Based Safe Drinking Water Alternative for Fluoride Affected Areas of Nalgonda District. Andhra Pradesh", A Pilot Study, AWAM \& Professional Social Workers Consortium, Hyderabad, Andhra Pradesh

[19]. Townsend, R (1995), "Risk and insurance in village India", Econometrica, Vol. 62, pp. 539-592.

[20]. World Health Organization, (2001) "Health in the Context of Sustainable Development: Background Document", Prepared by Y. von Schirnding and C. Mulholland, WHO/HDE/HID/02.6

[21]. World Bank (1993), Water Quality: Assessment and Production, Water Resources and Environment Technical Note No. D 1, Washington DC 